\title{
Traditional and Advanced Flow Characterization Techniques: A Platform Review for Development of Solid Dosage Form
}

\author{
K. K. MORAVKAR, S. D. KORDE, B. A. BHAIRAV, S. B. SHINDE, S. V. KAKULADE AND S. S. CHALIKWAR* \\ Department of Quality Assurance, R. C. Patel Institute of Pharmaceutical Education and Research, Karwand Naka, Shirpur, \\ Dhule, Maharashtra 425405, India
}

Moravkar et al.: PReview on flow characterization techniques

\begin{abstract}
Preformulation studies like storage, transfer, fluidisation, and compaction, are subject to the excellent flowability of the powder. It is often required for proper operational management and consistent design of industrial processes. Two basics methods have been utilised to characterise the flow behaviour of bulk solids. Traditionally, powder has been evaluated in terms of simple and straight forward techniques like Hausner's ratio, Carr's index, bulk density, and angle of repose. Despite that, the results obtained in the traditional method lack predictability, reproducibility, sensitivity, and the actual association between the resulting data and flow behaviour. Henceforth the results varied for weight variation, content uniformity, and dissolution, etc. during the preparation of final dosage forms. To overcome these limitations of the traditional methods, the advanced techniques are being utilised to explore micro properties like the angle of internal friction, bulk density, flow function, yield loci, powder rheometry under precisely controlled conditions of consolidation stress. Ultimately these techniques help to design, choose suitable excipients, reduce time along with cost, and improve the health of society. This review focuses on some of the most commonly applied methods used in traditional and advanced shear cell testing techniques to measure the flow of powders.
\end{abstract}

Key words: Powder characterisation, advanced powder flow techniques, Schulze ring shear tester, Brookfield powder flow tester, Jenike tester, FT4 rheometer

Dry powder is one of the most fundamental forms that emanate at some point during the manufacturing lifecycle of most of the products in many industries such as food, chemical, and pharmaceuticals ${ }^{[1]}$. The use of fine cohesive powder during the formulation of a product is expected in the pharmaceutical industry, and the characteristics of cohesive powder have a significant influence on its flow property which is subsequently known to affect the product performance. For example, the problems commonly observed in the tablet formulation such as weight variation or non-uniformity in tablets are mostly attributed to the improper flow of powder in the die cavity ${ }^{[2,3]}$. Generally, in cohesive powder strong inter particle forces like the Van der Waals force causes poor flowability of powders which reduces the tendency of particles to segregate. It also causes agglomeration of a particle, which led to improper flow of powder through the hopper when the mass powder handling is required.

*Address for correspondence

E-mail: pharmashailesh@rediffmail.com

November-December 2020
Powder flow is governed by various factors, which include size, size distribution, shape, surface roughness, and moisture content. Larger particles possess better flow attributes as the effect of gravity outweighs inter particulate attractive forces such as the van der Waals forces. As the particle size decreases, van der Waals forces become more dominant, contributing to greater cohesiveness and resistance to flow especially when the particles are smaller than $20 \mu \mathrm{m}$ in size. The flowability of powders with narrower size distributions increased more significantly with size. The shape of powder had a greater impact on flow than size when particle size was about $30 \mu \mathrm{m}$ or smaller. Generally, the aspect ratio,

This is an open access article distributed under the terms of the Creative Commons Attribution-NonCommercial-ShareAlike 3.0 License, which allows others to remix, tweak, and build upon the work non-commercially, as long as the author is credited and the new creations are licensed under the identical terms

Accepted 26 November 2020 Revised 18 August 2020 Received 12 January 2021 Indian J Pharm Sci 2020;82(6):945-957 
roundness, and irregularity of the materials used to shape the characterization of the particles. Spherical shaped particles have better packing, lower compressibility, and decreased contact area, which collectively contribute to the flowability of the powder. The effect of moisture on powder flowability depends on the amount of water and its distribution. Lower amounts of water might have a positive effect on powder flow, as it can eliminate particle micro irregularities and electrostatic charges. While a higher amount of water will increase the thickness of the adsorbed liquid layer, resulting in the powder becomes more cohesive and tends to form agglomerates ${ }^{[4-6]}$.

Further, the flow of powder through the hopper or bins is essential because changes in the flow property of powder can lead to many problems such as flow obstruction, improper flow, shock, and vibrations. The rat holing or arching is the most common problems due to the inappropriate discharge of powders. Creating a consistent flow from the hopper requires reliable information about the flow properties of powder is crucial $^{[7,8]}$. Thus, the knowledge of flow characteristics of bulk powder is key to predict the flow performance, which is essential for processing operation with a cohesive pharmaceutical powder. Henceforth, the characterisation of the powder is critical in the pharmaceutical industry to ensure product performance as well as to design a hopper through which proper flow of powder can be achieved ${ }^{[8]}$.

In pharmaceutical industries, two major types of flow patterns can be followed that is mass flow and core flow or funnel flow.

Generally, mass flow is considered as an ideal pattern for the flow of powders where the bulk powder is in continuous motion, and there is no obstruction over the outlet of the hopper. The powder from the centre as well as from the peripheral edge moves toward the hopper outlet. The flow of powder in the hopper delivers as a "first in first outflow" pattern (fig. 1a). It reduces segregation, eliminates static powder, and provides the uniform flow of powders, and steady discharge with a constant bulk density. To achieve the mass flow pattern, good sizing and the large enough outlet dimension are required to avoid arching (fig. 1b), and the hopper edge should be smooth and steep adequate to help the continuous flow of powder at the walls ${ }^{[9-13]}$.

The basic of a funnel or core flow pattern is 'first in last out'(fig. 1c). It can be described as the powder flow from the centre core, which exists first at the hopper or bin, and then the remaining bulk powder flow or moves from the edge of the container. In core flow, the material or powder which enters the hopper first which gets steady state at the side of the hopper and the powder which is above the first powder which drains first from the core? If the material remains at the wall of the bin can lead to the formation of the rat hole in hopper and bins (fig. 1d). In general, the flow problems are caused by the core flow patterns and can be overcome by changing the flow pattern to mass flow. Thus, the measurement of powder flow properties is required to design the hopper, which can closely mimic the mass flow pattern ${ }^{[7,9,10]}$.

Different methods are used for the determination of the flow properties of pharmaceutical bulk powders. It can be categorised into two ways that are traditional and advanced techniques. Traditional methods used for the determination of flow properties such as tap density, bulk density, Carr's index, Hausner's ratio, and the angle of repose. The results obtained by these methods in term of flow properties which can be utilised for ranking, the quality control and comparison of powders. Although the traditional methods are more uncomplicated and straight forward, they lack sensitivity, predictability, reproducibility, and disparity between the obtained data and actual behaviour of bulk solids. These limitations have motivated researchers for the development of the advanced techniques to characterise the flow property of pharmaceutical bulk powder. Powder flow characteristics are often investigated using a variety of advanced and automated new cutting edge techniques that provide in depth material characterisation data, besides, to overcome the traditional focus of silo design $^{[14]}$. The current review article is an attempt to summarise the different conventional and advanced techniques used to characterise the flow property of powders.

\section{TRADITIONAL METHODS}

\section{Bulk density:}

Bulk density of powder can be defined as the mass of

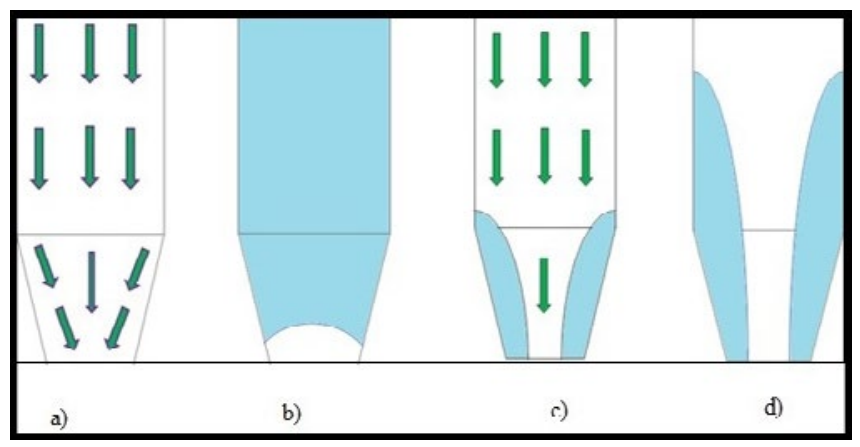

Fig. 1: Powder flow pattern (a) Mass flow, b) arching, c) core flow d) rat hole 
powder divided by volume occupied by the powder. When the bulk powder is transferred into the container, the container will occupy the volume known as initial volume, $\mathrm{V}_{0}$. The occupied volume of the container by powder is dependent on the individual particle arrangement. The frictional and inter particle forces can result in the formation of a powder bed consisting of both particles and void space ${ }^{[15-18]}$.

The bulk density varies significantly depending on different processes through which bulk powder passes, such as consolidation, packing, compaction. The bulk powder with a strong structural bonding will yield a low bulk density as it will lead to difficulty when it is dispensed or poured in the hopper or bin due to resistance occurs in the rearrangement of the packing of particles. On the other hand, bulk powder which has structurally weak bonds between the particles shows the higher bulk density. The structurally weak powder dispersed readily when left to settle, mostly it observed during tapping condition. Lower the frictional and inter particle forces of the particle which leads to more straight forward rearrangement of the particle, and it will lead to higher packing friction and bulk density ${ }^{[11,19]}$.

Bulk Density=Mass of sample/Volume

Eq. (1)

\section{Tap density:}

Tap density is defined as the ratio of the mass of the sample to the tapped volume called tapped density. Consolidation of powder particles will occur in a container that is filled with the powder due to applied energy in the form of mechanical disturbances or tapping. Applying taps lead to breaks and re-form the inter particle arrangement in the powder. Due to the tapping the loose powder which gets separate and lowers the friction between the particles. The outcomes of continuous taping are consequently decreased into a new volume of compact powder that is $\mathrm{V}_{\mathrm{n}}$, where the $\mathrm{n}$ is the no. of taps applied. Consolidation of powder particles will be stopped at a particular limit, even tapping of powder increases because the mass of powder remains constant ${ }^{[20-23]}$. The new volume resulted in a new density which is called tapped density, Pt. The tapped density is always higher than free flow apparent density ${ }^{[15]}$. In industrial applications, tap density is used to measure the degree of powder packing that occurs in the container during tapping. Tap density is dependent on the various powder characteristics such as particle porosity, particle shape, and particle size distribution. Among these, the particle shape of powder is the primary factor that changes significantly when bulk density is transformed into tap density. Generally, lower bulk density has a higher chance to increase the percent tap density ${ }^{[13,24-26]}$.

Tapped Density=Mass of sample/Tapped Density Volume

\section{Hausner ratio:}

In 1967, Hausner has described the relationship between bulk density and tapped density. The Hausner ratio can be defined as tapped density to bulk density. A higher value of the Hausner's ratio indicates poor flowability of powder and vice versa. This ratio indicates the ability of the bulk powder to rearrange inter particulate space presenting themselves during external force like tapping or vibration. Rearrangement of powder particles into inter particulate space is dependent on the cohesive strength of powder which can be reflected by Hausner's ratio. Although, Hausner's ratio cannot be considered as fundamental property due to some other independent variables that may have an impact on rearrangement, for example, wall friction effect applied by container, particle size distribution ${ }^{[25,27-29]}$.

Hausner ratio $=$ Tapped density/Bulk density

Eq. (3)

\section{Carr's index:}

In 1965, Carr described the relationship between the bulk density and the tapped density to determine the Carr's index of powder in equation (4) relationship also. This represented another term known as the compressibility of powder and expressed as a percentage. Carr's index is a quick and straight forward indirect method to measure the relative strength of inter particle and frictional forces of bulk powders. Standard values of Carr's index and Hausner's ratio is to determine the flow index, which defines in Pharmacopoeia gives the transition between free flowing powder and poor flowing powder (Table 1). In general, the higher the value of Carr's index indicates the poor flowing powder. The difference between the bulk and tapped density is larger in poor flow powder than the free

TABLE 1: STANDARD VALUES OF CARR'S INDEX AND HAUSNER'S RATIO

\begin{tabular}{lcc}
\hline Carr index & Hausner ratio & Flow property \\
\hline$\leq 0.10$ & $1.00-1.11$ & Excellent \\
$0.11-0.15$ & $1.12-1.18$ & Good \\
$0.16-0.20$ & $1.19-1.25$ & Fair \\
$0.21-.025$ & $1.26-1.34$ & Passable \\
$0.26-0.31$ & $1.35-1.45$ & Poor \\
$0.32-0.37$ & $1.46-1.59$ & Very poor \\
$>0.38$ & 1.60 & Very, very poor \\
\hline
\end{tabular}


flowing powder ${ }^{[15,25,30]}$. Carr's index $=$ Tapped densityBulk density/Tapped density $\times 100$

Eq. (4)

\section{Angle of repose:}

As compared to the various physical property of bulk powder, the angle of repose is more comfortable to obtain. The angle of repose is correlated with the inter particle friction and the flowability of cohesion less material. The angle of repose is used to characterise the bulk powder. The angle of repose has more practical interest than theoretical concern, and hence this property is frequently used to represent powdered materials. It is the aggregate angle of an unconstrained heap of solids with the horizontal. The results are not reproducible due to other inherent factors such as the presence of moisture in the environment, wall friction effect applied by container, etc. of material. However, to obtain a convenient characterisation of powdered material and standard result, ultimate reliability depends on the measuring methods used, which will be discussed further. The standard values are represented in Table 2.

The powder is passed from the funnel, which is fixed at a particular height until the apex of the heap formed by the powder reaches the funnel. The angle of repose is the ratio of the height to the mean radius of the base of powder heap ${ }^{[2,31,32]}$.

The angle of repose $(\theta)=\tan ^{-1} \mathrm{~h} / \mathrm{r}$

\section{Different methods for determination of the angle of repose:}

\section{Method I Fixed funnel and free-standing cone}

The powder is carefully passed through the funnel. The funnel, which is fixed at a particular height and powder passed through the funnel, formed the apex of the heap, which reaches the tip of the funnel (fig. 2). The tangent of the angle of repose is the ratio of the height $(\mathrm{h})$ to the mean radius $(r)$ of the base of the powder pile, the mathematical expression represented in Equation $6^{[33]}$.

TABLE 2: STANDARD VALUES OF ANGLE OF REPOSE $(\theta)$

\begin{tabular}{lc}
\hline Flow property & Angle of repose $(\theta)$ \\
\hline Excellent & $25-30$ \\
Good & $31-35$ \\
Fair (aid not needed) & $36-40$ \\
Passable (material may hang up) & $41-45$ \\
Poor (must agitate, vibrate) & $46-55$ \\
Very poor & $56-65$ \\
Very, very poor & $>66$ \\
\hline
\end{tabular}

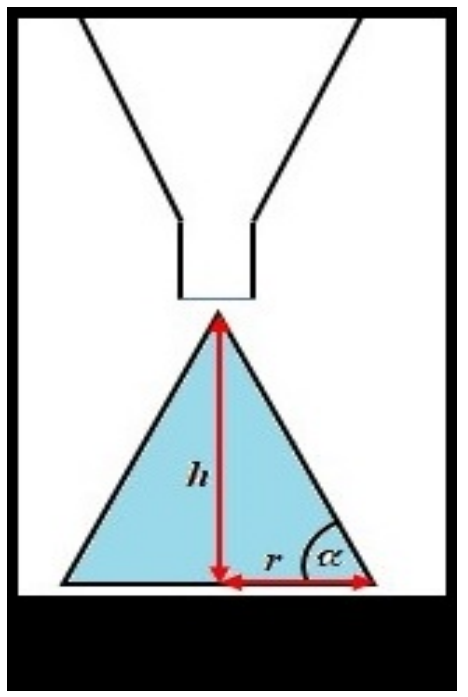

Fig. 2: Fixed funnel and free-standing cone method for determination of angle of repose

The angle of repose $(\theta)=h / r \quad$ Eq. (6)

\section{Method II Fixed bed cone}

In the "fixed base cone" method (fig. 3), the powder is allowed to flow through a centre of the funnel which can be elevated vertically until a maximum cone height $\mathrm{H}$ is obtained. Sharp edge circular base dish is used, which has a fixed diameter. The tangent of the internal angle between the free elevated edges to the horizontal base is known as angle of repose that is $\tan \alpha$ being calculated in the same manner as the fixed height cone method $^{[13,15,24,33]}$.

\section{Method III Tilting box}

In the "tilled box" method (fig. 4), the rectangular box is filled with powder and leaned until the contents begin to roll over. The angle between the upper surfaces of the box to the horizontal base is taken as the angle of repose $^{[33-36]}$.

\section{Method IV Revolving cylinder}

A sealed hollow cylinder which is half-filled with the powder revolves horizontally and can be observed with the transparent end of the cylinder (fig. 5). During the revolution, the maximum angle form between rotating powder to a horizontal surface is known as the angle of repose $^{[13,33,37]}$.

Although, these traditional methods give an indication about the flow properties of powders but not the in depth understanding, and besides reproducibility is also a major issue. Powders should be described in terms of flow function, bulk density, wall friction, angle of internal friction, consolidated stress, hopper design, 


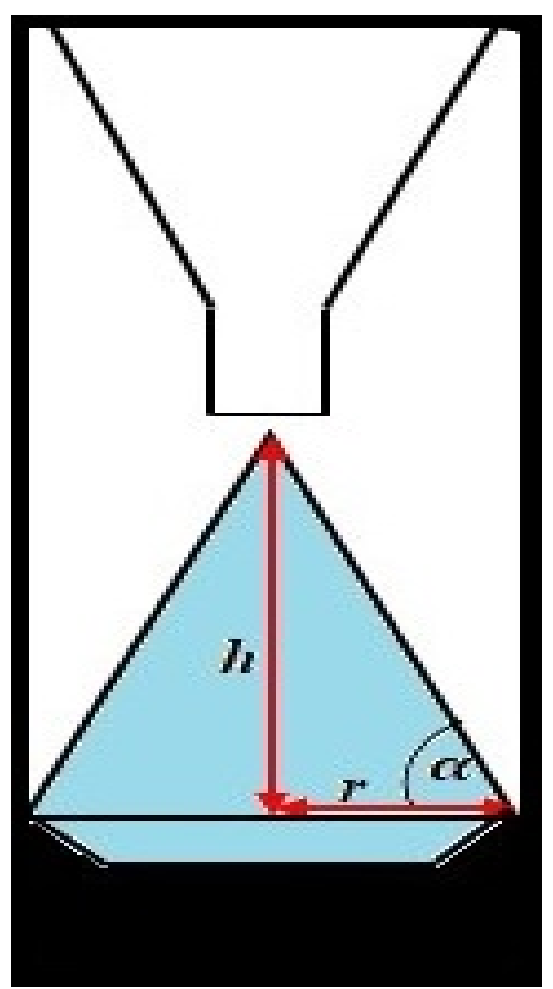

Fig. 3: Fixed bed cone method for determination of angle of repose

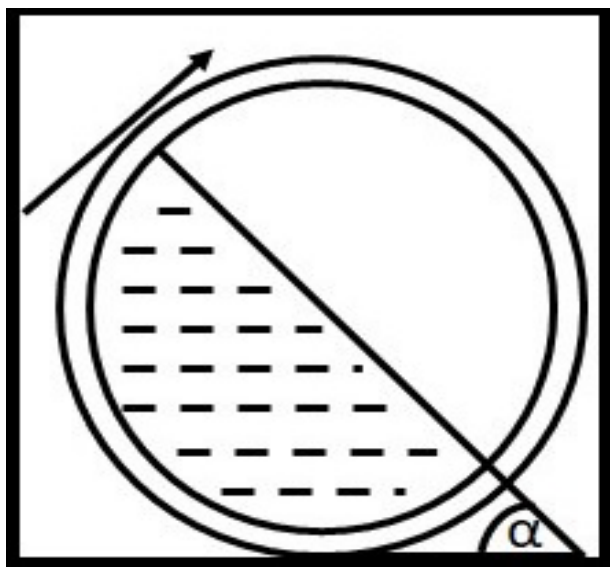

Fig. 4: Tilting box method for determination of angle of repose

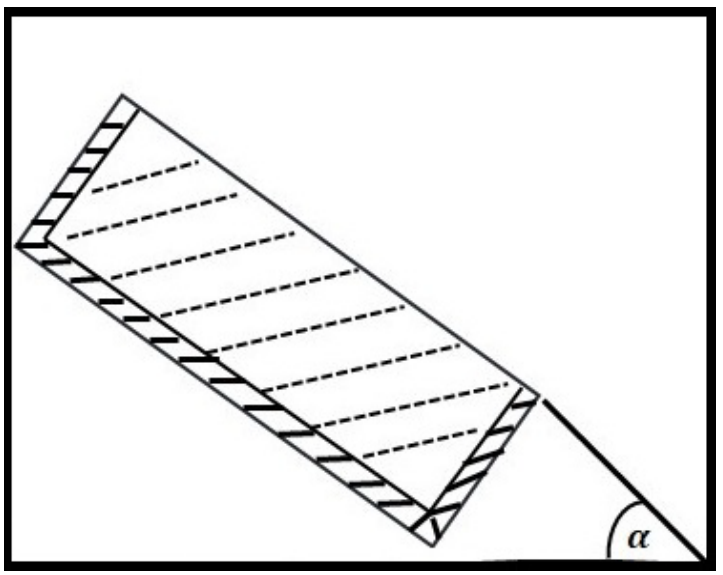

Fig. 5: Revolving cylinder method for determination of angle of repose

November-December 2020 hopper half angle, and other parameters like rat hole dimension, arching dimension. All of these factors play an important role in the behaviour of bulk solids during the manufacturing of finished products. To overcome all these loop holes in the traditional method, there is a need for the reengineering of the existing system.

\section{ADVANCED TECHNIQUES}

To overcome the limitations of the traditional methods of flow property measurements, several advanced techniques have been proposed, which has many advantages over them, as discussed in this section. In the last several decades; various testers are developed to measure various powder properties in a reproducible and robust way. The available testers can be categorised into direct and indirect testers, based on their working principle (fig. 6) ${ }^{[38]}$. Some scientists also classified these advanced testers as consolidated (shear) testers ${ }^{[39]}$. These advanced shear testers play a significant role in the design of different reliable equipment such as silos, storage bins, and hoppers which can handle various bulks. Shear testers, also are used to determine different flow properties of powder such as consolidation stress, hopper half-angle, frictional angle, etc. The shear cell testers have a solid theoretical base as well as science based technology support and hence the use of these technologies tremendously increased in the industry. However, an in depth evaluation is undertaken, the different technical outcomes reported during the measurement and analysis of testing powders. End users should be aware of such analytical results, significant shortcomings, and interpretation of the results. The different reported terms in advanced techniques allow the end-users to rank different powders. This section will briefly outline different terms used in interpreting shear data and shear testers from the direct and indirect methods, which are mostly used for the flow property measurement.

\section{Shear test data evaluation:}

A computer based program can do data evaluation of shear cell testing. Shear testers measure the different normal and shear stresses and generate various parameters (Table 3 ) by the mathematical treatment of the applied stresses.

Historically, in 1960, A. W. Jenike took steps forward for the development of a bulk powder testing instrument ${ }^{[40]}$. The basic concern of his research was to determine the flowability of bulk solids from storage vessels and to characterize the flowability. He used an adapted civil 


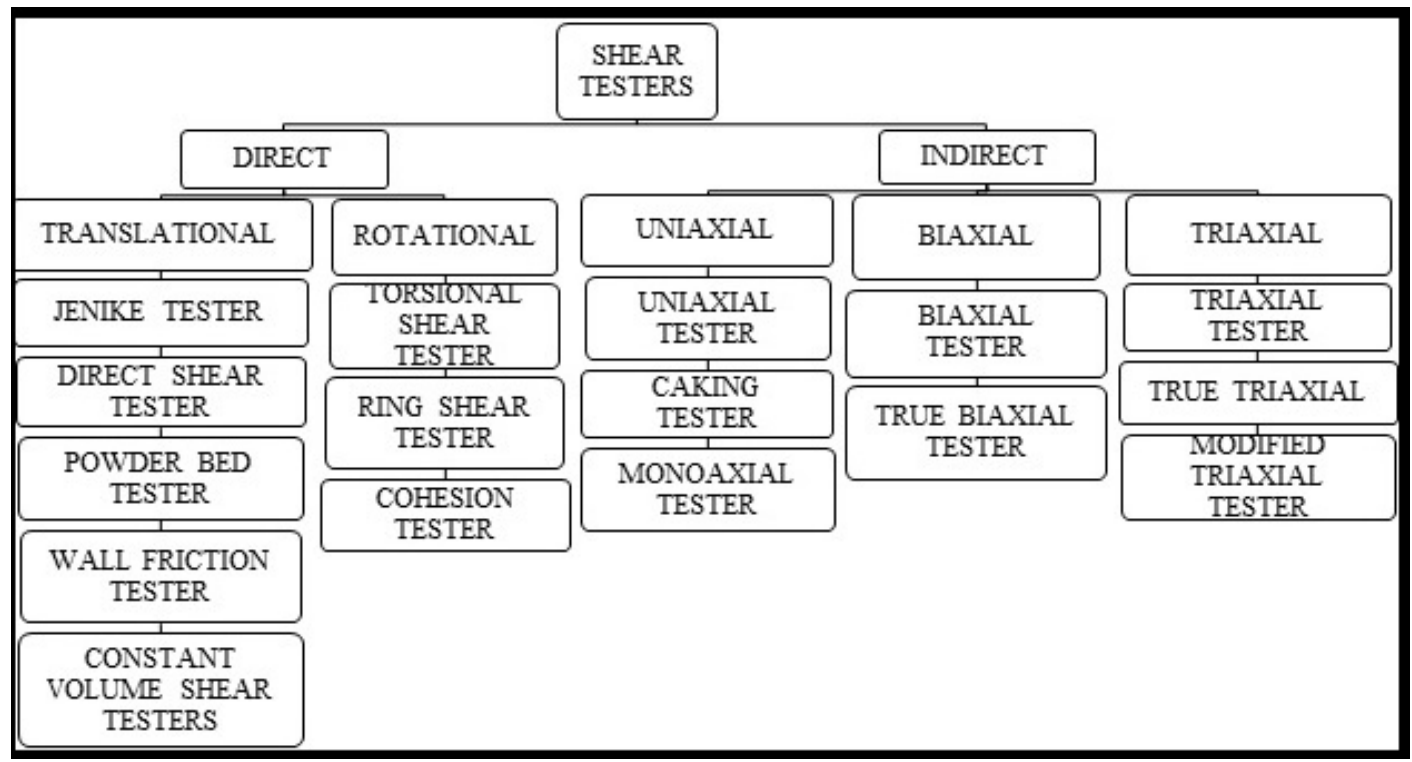

Fig. 6: Classification of advance shear tester

\begin{tabular}{|c|c|c|}
\hline Parameter & Symbol & Units \\
\hline Major principal stress & $\sigma_{1}$, MPS & $\mathrm{Pa}$ \\
\hline Unconfined yield strength & $\sigma_{c,}$ FC, UYS & $\mathrm{Pa}$ \\
\hline Cohesion & C & $\mathrm{Pa}$ \\
\hline Flow function $\left(\sigma_{1}, \sigma_{c}\right)$ & $\mathrm{ff}_{\mathrm{c},} \mathrm{FF}$ & - \\
\hline Angle of internal friction & $\delta$, AIF & deg \\
\hline Effective angle of internal friction & $\delta_{e}, \operatorname{AIF}(E)$ & deg \\
\hline $\begin{array}{l}\text { Angle of internal friction at steady } \\
\text { state flow }\end{array}$ & $\delta_{\mathrm{ss}}, \operatorname{AIF}(\mathrm{SS})$ & deg \\
\hline
\end{tabular}

engineering shear box to characterize the different stresses act on solid particles.

Mohr's pressure cycle is a way of analyzing pressures firmly. Mohr circles associate shear pressure to normal pressure. The Mohr's circle represents the pressures on all cutting planes, the angle $(\alpha)$ of the bonding pressure given when the powder has stopped. The normal pressures that apply to these planes are called Principle Stress. The Major Principle stress $(\sigma 1)$ is the largest stress, and the smallest is called Minor Principle stress $(\sigma 2)^{[41]}$. A hypothetical representation of Mohr's stress circle is given in (fig. 7).

The yield strength is an important indicator of the flowability of bulk solids; it develops during the flow channel of granular solids. Yield locus (YL) can be defined graphically for given consolidated stress as failure shear stress vs normal stress ${ }^{[9,42]}$. The effective yield locus (EYL) is represented by the envelope of Mohr's stress circle, which passes through the origin. It is basically for free-flowing powders. Unconfined



Fig. 7: Diagrammatic representation of Mohr's stress circle

yield strength $(\sigma c)$ is an important indicator to measure arching in solids in silos. When the vertically applied compressive strength gets familiar or made zero is called Unconfined yield strength (UYS) ${ }^{[43,44]}$. The unconfined yield strength $(\mathrm{Pa})$ is defined by the normal stress axis and the intersection points of the Mohr circle, which passes through the origin. The YL is tangent to the main consolidating strength, and it can be calculated from the Mohr circle with the usual stress axis that passes through the steady state point that is $\mathrm{V}$ (normal load) and S (shear force) (fig. 8). The angle of internal friction (deg.) can be defined as the ratio of the major and minor principal stresses at steady-state flow; however, it represents the friction between sliding layers of powder. The range of angle of internal friction varies between $30^{\circ}$ and $70^{\circ}$ for different nature of powders. The ratio between lines of major consolidation stress versus powder's Unconfined Failure Strength is called the flow function of the material. Flow function has no dimension, and this test can be classified as the solids according to flow function value (Table 4) established by 




Fig. 8: Graphical description of the yield locus and the parameters derived from the fitting of Mohr circles

TABLE 4: CLASSIFICATION OF POWDER FLOWABILITY BY FLOW FUNCTION

\begin{tabular}{lc}
\hline Type of flow & Flow function $(\mathrm{FF})$ value \\
\hline Easy-flowing & $10<\mathrm{FF}$ \\
Free-flowing & $4<\mathrm{FF}<10$ \\
Cohesive & $2<\mathrm{FF}<4$ \\
Very cohesive and non-flowing & $\mathrm{FF}<2$ \\
\hline
\end{tabular}

Jenike ${ }^{[44]}$.Such a fine parameter measurement produces a very repeatable and sharp description of the powder behaviour which is used in the following advanced shear testers $^{[45-47]}$.

\section{Jenike tester:}

The application of shear cell techniques to measure powder flow behaviour pioneered by Jenike in 1964. Mass flow is the ideal flow pattern during the manufacturing of the finished product. This pattern allows all the powder to follow an ideal motion and to move downwards towards the opening of hoppers. A hopper is a container tapered at downwards, and the hopper angle is the angle between the horizontal and tapered section. To design mass flow hoppers, it is important to the measurement of flow properties of powder through a reliable technique. Jenike developed the most proper technique that is 'Jenike Shear cell tester' for determining the flow properties. Jenike's methodology to hopper design considers the combined effects of the angle of friction between hopper wall and powder, bulk powder density, unconfined strength, and force of attraction acting between individual powder particles. Using this approach, researchers successfully measured the flow properties of powder as a function of consolidation stress to predict flow behaviour and able to develop a stress-based mathematical model to determine the hopper opening size and minimum hopper angle for mass flow behaviour of powder from taper shaped hoppers ${ }^{[9,48-50]}$.

American Society for Testing and Materials (ASTM) International Standard D6773 has been used as a Jenike ring shear tester for measurement of stress based powder flow property (fig. 9).The Jenike shear cell consists of a shear ring, a mold ring, a fixed cylindrical base, a twisting lid, and as a hearing lid. Aluminium is used in the manufacturing of the shear ring and the shear lid whereas brass used for the twisting lid, the mold ring and the base. The ring, base, and the mold ring are similar internal diameter that is $92 \mathrm{~mm}^{[24,40,51]}$.

\section{Procedure and analysis:}

Jenike shear tester is based on the principle of plastic failure analysis to characterise powder flow based on the Mohr Coulomb failure criteria. The Jenike shear tester consists of a bottom ring or mold ring, a ring lying above that called as the upper ring, and a lid. A normal shear force is applied to the centre of the lid. The lid is allowed to move by a motor-driven stem in the vertical without interfering with the ring, therefore total load to be applied on the powder in the cell. The bulk solid undergoes a shear deformation due to the displacement of the upper ring and the lid against the bottom ring. A sequential normal and consolidated stress is applied to the powder by the shear cell, which is controlled by a computer controlled software system. National Instrument, United States of America developed this application $^{[7,52-57]}$. 


\section{Schulze ring shear tester:}

Ring shear cell tester is an instrument widely used to measure the flow behaviour and properties of bulk solids/powders. The results obtained from the shear cell are independent of scale, offering additional measures, such as air permeability, which is used to design optimal equipment for handling large-scale powders. Previously available shear cells are the traditional types and give poor reproducibility. A commercially available Schulze ring shear tester has greatly reduced the amount of powder and effort needed, since last decade, discussed here ${ }^{[58,59]}$.

A Schulze Ring Shear Tester (RST-XS, Dietmar Schulze, Wolfenbuttel, Germany) is used for measuring the flow properties of bulk solids or powder (fig. 10). Schulze RST which is equipped with either S-cell that is shown in fig. 10a or M-cell that is shown in fig. 10b. M-cell has an inside and outside tubular diameter of $102 \mathrm{~mm}$ and $198 \mathrm{~mm}$, respectively and S-cell has an inside and outside tubular diameter of 62 and $118 \mathrm{~mm}$, respectively. The internal volume of M-cell is $942 \mathrm{~cm}^{3}$ more compared to S-cell, which is $96 \mathrm{~cm}^{3[56,58]}$.

\section{Test procedure and analysis:}

A sample powder must be passed through a $0.5 \mathrm{~mm}$ sieve. The sieved powder over filled into a $10 \mathrm{ml}$ volume shear cell. Before scrapping off excess powder, the powder should be slightly compacted using a spatula which removes the air sacks present in bulk powder. After weighing the filled shear cell, it should be placed into the tester which is driven by a mechanical motor. A wide range of normal stresses like 1, 3, 6, 9, and 15 $\mathrm{kPa}$ can be used in this study yet stresses higher than $6 \mathrm{kPa}$ do not necessarily present in hoppers used in pharmaceutical purposes. Using the point to point approach or linear regression, a yield locus that is shear stress vs normal stress during shear can be obtained. The major principal stress (s) and the unconfined yield

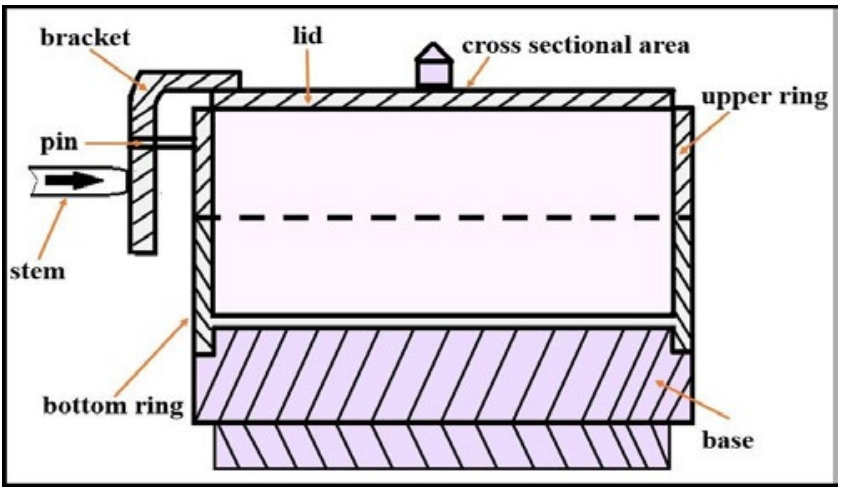

Fig. 9: Jenike shear tester 
properties of bulk solids or sample powder (fig. 11). The Brookfield PFT tester is equipped with the tubular trough which has an internal volume of $230 \mathrm{~cm}^{3}$ and an external tubular diameter $152.4 \mathrm{~mm}$. The volume of the vane lid is $33 \mathrm{~cm}^{3}$.

\section{Test procedure and analysis:}

The Brookfield PFT is also a type of RST. The principle operation of the PFT is similar to the working principle of the Schulze tester. The PFT drives a compression vertically through the lid into a powder sample filled in the annular trough. A defined volume of sample powder can be placed into the stationary lid and weigh before the start of the test. Two types of lids are used for

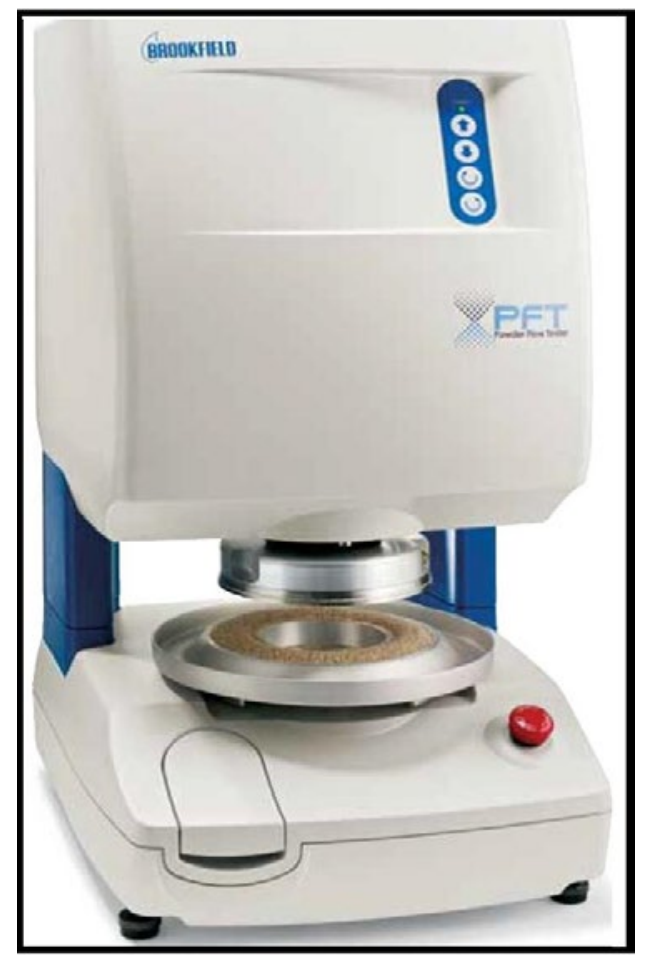

Fig. 11: Brookfield PFT for measurement of powder behavior testing powder flow. The Vane lid (fig. 12a) was used to carry out the Standard flow function test while the flat lid (fig. 12b) for the Standard wall friction test ${ }^{[68]}$. A sequential normal and consolidated stress applied to the powder by calibrated beam load annular cell which is controlled by the 'powder flow pro software'. Powder Flow Pro software analyses the raw data and it provides hopper half-angle, flow function curves, bulk density graph, wall friction angle graph, yield locus, angle of internal friction, and time consolidation information. For the standard flow function tests, the applied uniaxial normal stresses recommended in the range between 0.2 and $4.8 \mathrm{kPa}$. For the standard wall friction test, 10 normal stresses recommended range between 0.4 and $4.8 \mathrm{kPa}$. The maximum stress that can be applied by PFT is $4.819 \mathrm{kPa}$. A torque sensor was used to measure the resistance of the powder against the annular shear cell moving at a defined rotational speed (recommended $1 \mathrm{rev} / \mathrm{h}$ ). All the above parameters contribute to measuring the effective angle of internal friction, the yield loci, angle of wall friction and the flow function, and other flow properties of the powder ${ }^{[11,66,69]}$.

\section{FT4 Powder Rheometer (Freeman Technology):}

The FT4 Powder Rheometer (Freeman Technology) is used worldwide as a PFT for measuring powder behaviour and powder flow properties. The primary function of FT4 is to characterise the powder flow properties or rheology of powders. It is used to the characterisation of shear, wall friction, permeability, compressibility, and density, construct the most comprehensive understanding of how a powder behaves. Using this device, it is possible to predict the powder processing conditions such as in the moderately stressed, consolidated, aerated, or fluidised state.

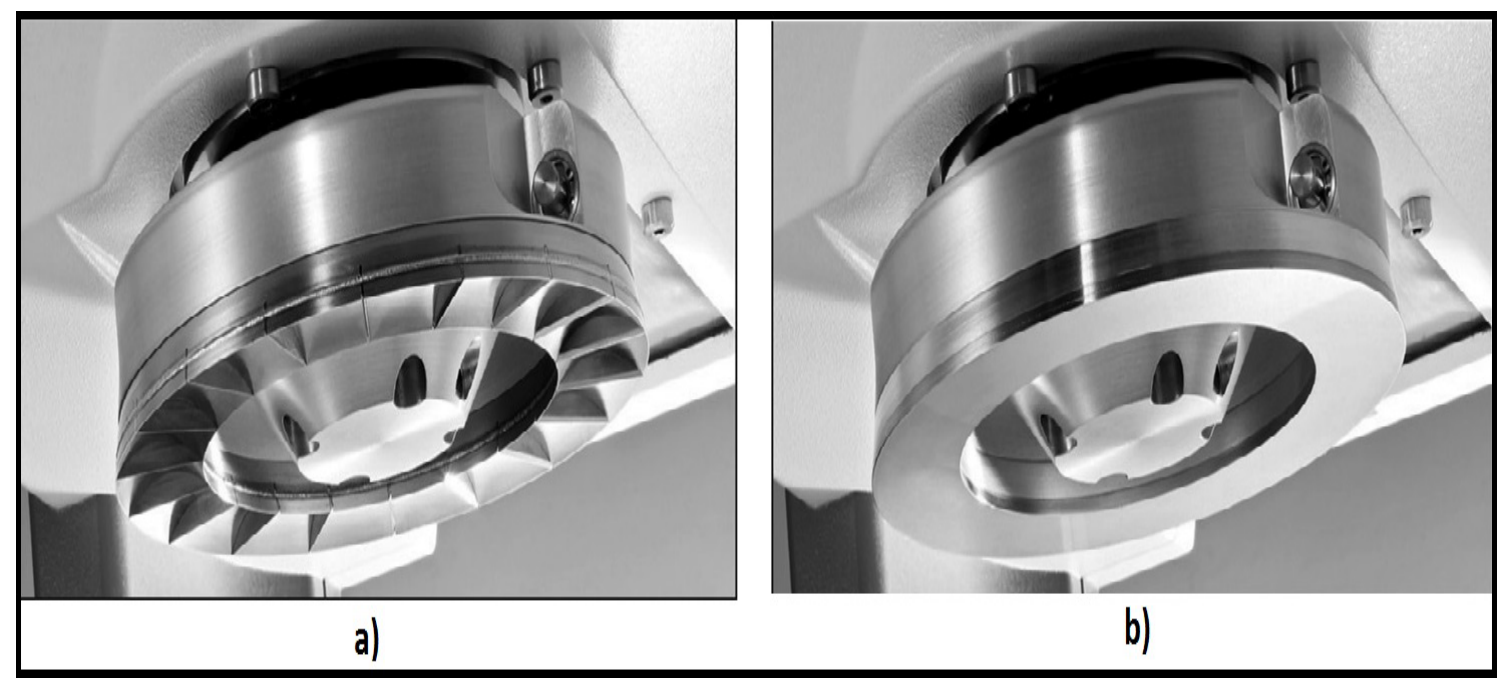

Fig. 12: Bottom side of the Vane Lid (a) and Wall Friction Lid (b) of PFT 
Unparalleled sensitivity, enabling the differentiation of powders is the unique benefit of FT4 among others ${ }^{[70]}$. FT4 (Freeman technology) powder Rheometer ${ }^{\circledR}$ used to characterised the behaviour of bulk solids.

The FT4 has a unique technology to measure the powder's resistance to flow, the energy required to diminish it and make them flow. The working principle of a device is based on a twisted blade that rotated and moved downwards to pass through a powder filled into a trough and establish a precise flow pattern, as shown in fig. 13. During the precise flow pattern of the moving blade, the resistance experienced by the blade is due to difficulty in relative particle movement. The more the particles resist the motion of the moving blade and the harder it is to get the powder to flow. The forces applied by moving blades for the deformation and flow of the powder are measured continuously in terms of energy consumed to make the powder flow. Different flow patterns can be achieved using a blade by adjusting the direction and axial and rotational speeds. Generally, two basic styles are used in the test procedure: conditioning cycle and the test cycle. Both the test creates a confined high shear stress region ahead of the blade. A shear cell measurement was used to determine the powder's shear strength. Impact of powder shear on the wall of the process equipment determined by a wall friction kit, the test results utilise to design hoppers and silos ${ }^{[14,71-73]}$.

\section{Procedure and analysis:}

The unique dynamic methodology used in the FT4 rheometer where flow resistance of powders is measured while the powder is in motion. Briefly, a sample powder is first positioned in a cylindrical vessel (fig. 13), and then it is impacted by dynamic blades when it passes through the powder bed. It is then slowly pre compacted with a vented piston under a defined normal load, i.e. between 0.5 to $15 \mathrm{kPa}$. The test results of powder

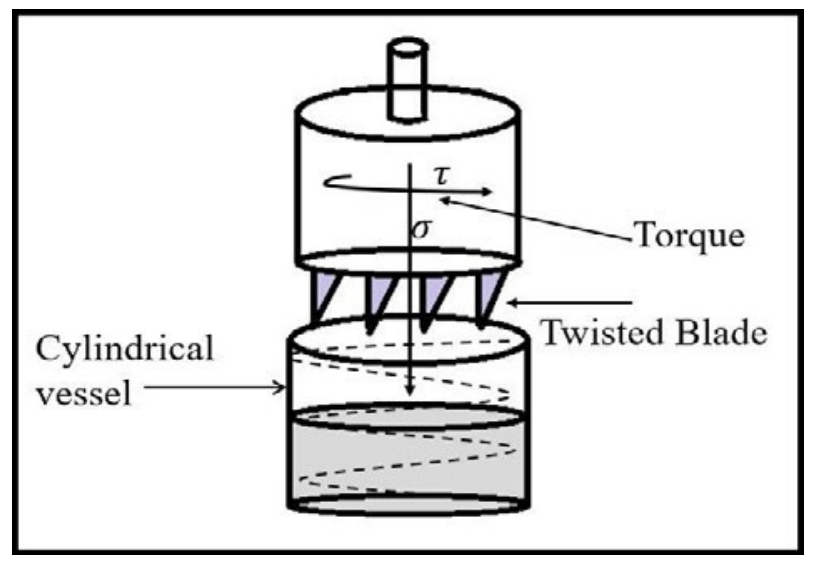

Fig. 13: FT4 Rheometer instrument for measurement of powder behaviour compression can be graphed against the standard stress $\sigma$. After pre compaction steps, the sample are conditioned with pre shared stress and prepared to achieve a critically consolidated state. At decreasing, normal loads $\sigma$ and the shear stress pretends the flow behaviour. The pre compaction and consolidation stress is repeated to obtain the yield locus. Using Mohr's circle analysis and yield locus, various important parameters can be determined such as unconfined yield strength, cohesion strength, and effective angle of internal friction, major principal stress, and other flow properties of powder ${ }^{[70,72,74-76]}$.

\section{Technical comparison:}

All different flow tester shows the difference in the results, depending on the properties of the material and the mechanisms of the different flow measurement testers ${ }^{[77]}$.The Brookfield PFT has differed from the Schulze and the Jenike based on the standard procedure applied to these instruments. The main aspects of these standard procedures are given as follows. The repeated initial consolidation stress results repeated the corresponding value of maximum consolidation stress applied at a particular load. It also differs based on the measurement of yield locus, values of cohesion, and internal friction angle due to additional shear data points ${ }^{[58]}$. The detail comparison as given below

\section{The time series of shear stress:}

Shear displacement characterize based on the rotational speed of trough and the time required for same. Schulze tester requires the least shear displacement than PFT to attain the steady-state. While the Jenike seems to require a shorter displacement during low-consolidation stresses. PFT shows certain delay in the co-sequences of the trough, lid, and motor which exhibit in the shear stress curve of the instrument ${ }^{[78]}$.

\section{The Yield loci:}

The yield loci obtained from the entire tester are the same for free flowing and cohesive powder. However, the Jenike tester can be shown significant deviation at lower values of normal stresses. Some-times PFT tester represented yield loci at negative intercept due to its automated procedure of analysis. The graph of Mohr's circle obtained by PFT and Schulze tester is similar, which is larger for the Jenike tester during testing of powder behavior ${ }^{[69,79]}$.

\section{Based on the flow properties:}


The cohesive strength identification of powder is similar at lower range consolidation stresses for the entire tester, while results varied with increasing the same. For the free flowing powder, cohesion values of the Schulze and the Jenike testers increased when raising the consolidation stresses, whereas the values are much less dependent on consolidation for the PFT. While comparing to very cohesive powder, the Schulze tester gives larger cohesion values among others. Considering the angle of internal friction the Jenike tester has not shown any significant change of frictional angle with consolidation, others have shown a decline of frictional angle with decreasing consolidation. The flow function factor and the powder bulk density, both directly depend on the range of consolidation applied to the powder ${ }^{[14,79]}$.

\section{CONCLUSION}

Flow properties of bulk powder or solids materials cannot be forecast by only one index. Several analytical methods are required to analyse and to build a complete understanding of the powder flow behaviour. The linking of all analytical results allows a better approach to design equipment. During free surface conditions, the conventional characterisation techniques like Hausner's ratio, Carr's index are well established and create a proper distinction between wide ranges of powders. These techniques are straight forward and well established; however, the initial powder pouring, strongly influence the results. Therefore, the reproducibility, sensitivity of these traditional techniques has limitations that depend on the involvement of the operator. In contrast to these techniques, the precise control conditioning procedure of advance techniques ensures repeatability and minimises the operator dependency. The data obtained by fully automated rotational shear tester are applied to derive hopper design in such a way that the bulk solids do not have time to form rat holes. Among the various parameters, the different state of consolidation stress, wall friction, and the bed voidage significantly impact the flow behaviour. Stress history (unconfined yield strength, yield loci, Mohr stress circle) and anisotropic behaviour affected on the strength of a bulk solid. It can be obtained by ensuring the steady-state flow of powder at different consolidation stress. All testers discussed in this review can be judged by their potential to analyse flowability. The comparison between the advanced shear cells testers mentioned can be made on the basis of normal shear stress, pre shear stress, and quantities of yield loci. In the PFT, shear and pre shear stress values are fixed, while different stresses can be allowed by
Schulze and Jenike testers. Loading values and different time series are also different among testers. Therefore, Jenike and Schulze testers are the only possible tester for comparison between these indices. The fluidisation, dynamic, and aeration test methods were carried out in the FT4 powder rheometer to determine equipment design and individual particle properties. It must be accepted that the existing testers have their advantages and disadvantages, and test procedures will not be precise in all aspects.

\section{Acknowledgements:}

This review article is the motivational compilation against the research grant sanctioned for Powder Flow Tester to the author Dr. S. S. Chalikwar. Thus, the authors are grateful to All India Council for Technical Education (AICTE), New Delhi, India, for the financial support of earlier project under research promotion scheme (Project no. 8-96/RIFD/RPS/ POLICY-3/2013-14). The authors extend their gratitude to the Management and Principal Dr. S. J. Surana of R. C. Patel Institute of Pharmaceutical Education and Research, Shirpur for providing essential facilities and supportive encouragement.

\section{Conflict of Interests:}

The authors declared no conflict of interest.

\section{REFERENCES}

1. Kojima T, Elliott JA. Effect of silica nanoparticles on the bulk flow properties of fine cohesive powders. Chem Eng Sci 2013;101:315-28.

2. Lachman L, Lieberman HA, Kanig JL. The theory and practice of industrial pharmacy. Lea \& Febiger; 1986.

3. Li Q, Rudolph V, Weigl B, Earl A. Interparticle van der Waals force in powder flowability and compactibility. Int J Pharm 2004;280(1-2):77-93.

4. Sandler N, Reiche K, Heinamaki J, Yliruusi J. Effect of moisture on powder flow properties of theophylline. Pharmaceutics 2010;2(3):275-90.

5. Tay JY, Liew CV, Heng PW. Powder flow testing: judicious choice of test methods. AAPS PharmSciTech 2017;18(5):184354.

6. Yu W, Muteki K, Zhang L, Kim G. Prediction of bulk powder flow performance using comprehensive particle size and particle shape distributions. J Pharm Sci 2011;100(1):284-93.

7. Chen P, Yuan Z, Shen X, Zhang Y. Flow properties of three fuel powders. Particuology 1(4):438-443.

8. Humayun Q, Hashim U, Ruzaidi CM. Structure characterization of low cost fabricated soft material built microchannel. Mater Sci Forum 2016;857:578-82.

9. Fitzpatrick JJ, Barringer SA, Iqbal T. Flow property measurement of food powders and sensitivity of Jenike's hopper design methodology to the measured values. J Food Eng 2004;61(3):399-405.

10. Emery EM. Flow properties of selected pharmaceutical 
powders: Citeseer; 2008

11. Garg V, Mallick SS, Garcia-Trinanes P, Berry RJ. An investigation into the flowability of fine powders used in pharmaceutical industries. Powder Technol 2018;336:375-82.

12. Garg V, Mallick SS. An Experimental Investigation into the Flow Properties of Pharmaceutical and Detergent Powders; 2017.

13. Carson J, Pittenger BH, Marinelli J. Characterize Bulk Solids to Ensure Smooth Flow. Chemical Engineering 2016;123(4):50.

14. Freeman R. Measuring the flow properties of consolidated, conditioned and aerated powders-a comparative study using a powder rheometer and a rotational shear cell. Powder Technol 2007; 174(1-2):25-33.

15. Tan G, AV Morton D, Larson I. On the methods to measure powder flow. Curr Pharm Des 2015;21(40):5751-65.

16. Rohokale SS, Dhanorkar YD, Pahuja V, Kulkarni GT. Characterization of selected polysaccharide hydrogels as pharmaceutical excipients. J Chronotherapy Drug Deliv 2012;3(2):41-54.

17. Ortega-Rivas E. Characterization and processing relevance of food particulate materials. Part Part Syst Charact 2012;29(3):192-203.

18. Sahin S, Sumnu SG. Size, shape, volume, and related physical attributes. In: Physical Properties of Foods. Springer, New York; 2006 .p. 1-37.

19. Liu H, Jie C, Ma Y, Wang Z, Wang X. Synthesis and Processing Effects on Microstructure and Mechanical Properties of Forsterite Ceramics. Trans Indian Ceram Soc 2020;79(2):83-7.

20. Castellanos A. The relationship between attractive interparticle forces and bulk behaviour in dry and uncharged fine powders. Adv Phys 2005;54(4):263-376.

21. Prescott JK, Barnum RA. On powder flowability. Pharm Technol 2000;24(10):60-85.

22. Martin CL, Bouvard D, Shima S. Study of particle rearrangement during powder compaction by the discrete element method. J Mech Phys Solids 2003;51(4):667-93.

23. Fatah N. Study and comparison of micronic and nanometric powders: Analysis of physical, flow and interparticle properties of powders. Powder Technol 2009;190(1-2):41-7.

24. Jenike AW, Johanson JR. On the theory of bin loads; 1969.

25. Pharmacopeia US. USP chapter $<616>$ bulk density and tapped density. Rockville: United States Pharmacopeia (USP) 2006:2638.

26. Patankar AN, Mandal G. The packing of solid particles: a review. Trans Indian Ceram Soc 1980;39(4):109-19.

27. Moravkar KK, Ali TM, Pawar JN, Amin PD. Application of moisture activated dry granulation (MADG) process to develop high dose immediate release (IR) formulations. Adv Powder Technol 2017;28(4):1270-80.

28. Banerjee S, Chaurasia G, Pal D, Ghosh AK, Ghosh A, Kaity S. Investigation on crosslinking density for development of novel interpenetrating polymer network (IPN) based formulation. J Sci Ind Res 2010;69(10):777-84.

29. Kulkarni PA, Berry RJ, Bradley MS. Review of the flowability measuring techniques for powder metallurgy industry. Proceedings of the Institution of Mechanical Engineers, Part E: J Process Mech Eng 2010;224(3):159-68.

30. Moravkar KK, Ali TM, Pawar JN, Amin PD. Comparative study of three granulation techniques: moisture assisted granulation technique, roller compaction and hot melt extrusion technique with maltodextrin DE16, PVP K12 and HPC as polymeric binders. Indo Am J Pharm Res 2016;6(5):5407-19.

31. Mehta A, Barker GC. The dynamics of sand. Rep Prog Phys
1994;57(4):383.

32. Carson JW, Pittenger BH. Bulk properties of powders. ASM Handbook: Powder Metal Technologies and Applications 2013;7:287-301.

33. Train D. Some aspects of the property of angle of repose of powders. J Pharm Pharmacol 1958;10(S1):127T-35T.

34. Khazaei J, Ghanbari S. New method for simultaneously measuring the angles of repose and frictional properties of wheat grains. Int Agrophys 2010;24(3):275-86.

35. Lee J, Herrmann HJ. Angle of repose and angle of marginal stability: molecular dynamics of granular particles. J Phys A Math Gen 1993;26(2):373.

36. Al-Hashemi HM, Al-Amoudi OS. A review on the angle of repose of granular materials. Powder Technol 2018;330:397417.

37. Ileleji KE, Zhou B. The angle of repose of bulk corn stover particles. Powder Technol 2008;187(2):110-8.

38. Schwedes J. Review on testers for measuring flow properties of bulk solids. Granul Matter 2003;5(1):1-43.

39. Ambrose RK, Jan S, Siliveru K. A review on flow characterization methods for cereal grain-based powders. J Sci Food Agric 2016;96(2):359-64.

40. Jenike AW. Storage and flow of silos. Bulletin 1964;123:89.

41. Menun C. A response-spectrum-based envelope for Mohr's circle. Earthq Eng Struct Dyn 2003;32(12):1917-35.

42. Singh BK, Ghosh K, Roy SS, Mondal B, Mandal N. Correlation between microstructure and mechanical properties of YSZ/ $\mathrm{Al} 2 \mathrm{O} 3$ ceramics and its effect on high speed machining of steel. Trans Indian Ceram Soc 2018;77(4):219-25.

43. Schulze D. Storage of powders and bulk solids in silos. Dietmar Schulze. Com; 2006.

44. Jenike AW. Storage and flow of solids. Bulletin No. 123 of the Utah Engineering Experiment Station; Utah Univ., Salt Lake City (United States) 1976;53(26).

45. Kasala S, Sudandara Doss MV. Microwave assisted synthesis and powder flowability characteristics of rare-earth Aluminate (ReAlO3, Re=La, Gd, Nd, Y) Powders. Trans Indian Ceram Soc 2019;78(1):13-9.

46. Selvakumar N, Ramkumar T. Effect of particle size of B4C reinforcement on Ti-6Al-4V sintered composite prepared by mechanical milling method. Trans Indian Ceram Soc 2017;76(1):31-7.

47. Khoshkalam M, Faghihi-Sani MA, Nojoomi A. Effect of zirconia content and powder processing on mechanical properties of gelcasted ZTA composite. Trans Indian Ceram Soc 2013;72(3):175-81.

48. Fitzpatrick JJ, Barry K, Cerqueira PS, Iqbal T, O'neill J, Roos YH. Effect of composition and storage conditions on the flowability of dairy powders. Int Dairy J 2007;17(4):383-92.

49. Ganesan V, Muthukumarappan K, Rosentrater KA. Flow properties of DDGS with varying soluble and moisture contents using jenike shear testing. In 2007 ASAE Annual Meeting, American Society of Agricultural and Biological Engineers, 2007:1.

50. Teunou E, Fitzpatrick JJ. Effect of storage time and consolidation on food powder flowability. J Food Eng 2000;43(2):97-101.

51. Carson JW, Wilms H. Development of an international standard for shear testing. Powder Technol 2006;167(1):1-9.

52. Leung LY, Mao C, Chen LP, Yang CY. Precision of pharmaceutical powder flow measurement using ring shear tester: high variability is inherent to powders with low cohesion. Powder Technol 2016;301:920-6. 
53. Schweiger A, Zimmermann I. A new approach for the measurement of the tensile strength of powders. Powder Technol 1999;101(1):7-15.

54. Juliano P, Muhunthan B, Barbosa-Canovas GV. Flow and shear descriptors of preconsolidated food powders. J Food Eng 2006;72(2):157-66.

55. Ladipo DD, Puri VM. Computer controlled shear cell for measurement of flow properties of particulate materials. Powder Technol 1997;92(2):135-46.

56. Schulze D. Round robin test on ring shear testers. Adv Powder Technol 2011;22(2):197-202.

57. Schwedes J. Measurement of flow properties of bulk solids. Powder Technol 1996;88(3):285-90.

58. Salehi H, Barletta D, Poletto M. A comparison between powder flow property testers. Particuology 2017;32:10-20.

59. Standard AS. D6773: Standard shear test method for bulk solids using the Schulze ring shear tester. ASTM International; 2015.

60. Swize T, Osei-Yeboah F, Peterson ML, Boulas P. Impact of shear history on powder flow characterization using a ring shear tester. J Pharm Sci 2019;108(1):750-4.

61. Deshmukh OS, Dhital S, Mantilla SM, Smyth HE, Boehm MW, Baier SK, et al. Ring Shear Tester as an in vitro testing tool to study oral processing of comminuted potato chips. Food Res Int 2019;123:208-16.

62. Hildebrandt C, Gopireddy SR, Fritsch AK, Profitlich T, Scherließ R, Urbanetz NA. Evaluation and prediction of powder flowability in pharmaceutical tableting. Pharm Dev Technol 2019;24(1):35-47.

63. Sun CC. Mechanism of moisture induced variations in true density and compaction properties of microcrystalline cellulose. Int J Pharm 2008;346(1-2):93-101.

64. Slettengren K, Xanthakis E, Ahrne L, Windhab EJ. Flow properties of spices measured with powder flow tester and ring shear tester-XS. Int J Food Prop 2016;19(7):1475-82.

65. Lopes Neto JP, Meira AS, Do Nascimento JW. Flow properties and pattern flow prediction of food industrial powders. Eng Agric 2017;37(4):627-36.

66. Ding XJ, Liu LL, Bradley MS. New Instrument PFT for Powder Flow Researching. Adv Mat Res 2012;508:141-5.
67. Wang Y, Koynov S, Glasser BJ, Muzzio FJ. A method to analyze shear cell data of powders measured under different initial consolidation stresses. Powder Technol 2016;294:10512.

68. Lee YJ, Yoon WB. Flow behavior and hopper design for black soybean powders by particle size. J Food Eng 2015;144:10-9.

69. Berry RJ, Bradley MS. Development of the Brookfield Powder Flow Tester. University of Greenwich; 2010.

70. Leturia M, Benali M, Lagarde S, Ronga I, Saleh K. Characterization of flow properties of cohesive powders: A comparative study of traditional and new testing methods. Powder Technol 2014;253:406-23.

71. Narang AS, Sheverev V, Freeman T, Both D, Stepaniuk V, Delancy $\mathrm{M}$, et al. Process analytical technology for high shear wet granulation: Wet mass consistency reported by in-line drag flow force sensor is consistent with powder rheology measured by at-line FT4 powder rheometer ${ }^{\circledR}$. J Pharm Sci 2016;105(1):182-7.

72. Forte G, Clark PJ, Yan Z, Stitt EH, Marigo M. Using a Freeman FT4 rheometer and Electrical Capacitance Tomography to assess powder blending. Powder Technol 2018;337:25-35.

73. Gnagne EH, Petit J, Gaiani C, Scher J, Amani GN. Characterisation of flow properties of foutou and foufou flours, staple foods in West Africa, using the FT4 powder rheometer. J Food Meas Charact 2017;11(3):1128-36.

74. Nan W, Ghadiri M, Wang Y. Analysis of powder rheometry of FT4: Effect of particle shape. Chem Eng Sci 2017;173:374-83.

75. Hare C, Zafar U, Ghadiri M, Freeman T, Clayton J, Murtagh MJ. Analysis of the dynamics of the FT4 powder rheometer. Powder Technol 2015;285:123-7.

76. Clayton J. Optimising metal powders for additive manufacturing. Met Powder Rep 2014;69(5):14-7.

77. Shi H, Mohanty R, Chakravarty S, Cabiscol R, Morgeneyer M, Zetzener $\mathrm{H}$, et al. Effect of particle size and cohesion on powder yielding and flow. KONA Powder Part J 2018:2018014.

78. Johanson K, Barletta D. The influence of air counter-flow through powder materials as a means of reducing cohesive flow problems. Part Part Syst Charact 2004;21(4):316-25.

79. Koynov S, Glasser B, Muzzio F. Comparison of three rotational shear cell testers: Powder flowability and bulk density. Powder Technol 2015;283:103-12. 